\title{
Optimum Distribution of Fish Production Between Egyptian Governorates
}

\author{
Dr. Eman AbdAllah AbdAllah Dr. Hammad Hosni Ahmed \\ Agricultural Economics Research Institute-Agricultural Research Center
}

\section{Introduction}

Animal protein is one of the main food groups necessary to ensure proper nourishment and human health. Animal proteins are nutritionally complete as they contain all the essential amino acids that our bodies cannot manufacture and thus must obtain through diet. Red Meats, poultry, eggs, and fishes are rich in several water-soluble vitamins and essential minerals. Dairy products are a plentiful source of calcium and phosphorus, both indispensable to bone health. Iron is also obtained from red meat, liver and eggs. As for Zinc, a mineral that supports immune health, is abundant in beef and lamb ${ }^{(1)}$.

Based on such facts, and knowing that there is a direct link between health and economic performance of the population, providing Egyptian consumers with their needs of animal protein is a top priority for policy makers. However, the high cost of red meat production and the rising cost of poultry production make it hard to obtain sufficient animal protein from both sources.

Fish is a high-protein, low-fat food that provides a range of health benefits. Whitefleshed fish, in particular, is lower in fat than any other source of animal protein, whereas oily fish are high in omega-3 fatty acids, or the good fats which are essential nutrients that human body cannot produce significant amounts of. Fish are also low in omega-6 fatty acids, which are the bad fats commonly found in red meat ${ }^{(2)}$.

Fortunately, Egypt is endowed with a wide water area, estimated at some 13.2 million feddans containing a variety of fish resources such as marine fisheries, water lakes, the Nile River, water canals and agricultural drainages, in addition to fish culture, which has lately been the major source of fish production in Egypt. It is worth mentioning that Egypt's total fish production during 2013 amounted to 1454401 tons, of which $24.48 \%$ come from natural resources, while the remaining $75.52 \%$ come from fish culture ${ }^{(3)}$.

Therefore, fishes, either from natural resources or cultured, are considered the safe haven for providing consumers with a cheaper source of healthy animal protein that can help them cover their body requirements.

\section{Research Problem}

Transportation of food commodities is one of the fundamental factors influencing food security by affecting consumers' access to, and affordability of obtaining food items. This situation applies to fresh fish, the transportation of which across Egypt is not planned and hence fish distribution between Egyptian Governorates is far from optimum. Therefore, consumers in those Governorates that are not endowed with natural fisheries, or even have fish resources but their demand is higher than available supply, are not able to obtain the adequate amount of fish that helps them satisfy, or complement their body needs of animal protein, which causes protein deficiency and risks human health thus economic performance. Accordingly, the research seeks to answer the following question: is it possible to provide policy makers with options for optimizing fresh fish distribution between Egyptian Governorates so as to 
improve consumers' access to, and affordability of obtaining fresh fish as a cheaper source of animal protein?

\section{Research Objectives}

The main aim of this research is to provide decision makers with two possible options regarding the optimum pattern of transporting domestic fresh fish production from supply to demand Governorates, either by minimizing the total spatial transportation distance thus time (first scenario), or by minimizing the cost of transportation thus reduce consumer prices (second scenario), which both eventually contribute to improving food security in animal protein.

\section{Methodology and Sources of Data}

Theoretically, distribution of available fresh fish supply should be based on identifying surplus and shortage regions. In other words, domestic production of fresh fish should be optimally distributed between shortage regions. To achieve that, the research depended on applying the Transportation Model to fresh fish transported from supply surplus to shortage Governorates under two scenarios, the first of which is the minimization of transportation distance, whilst the second is the minimization of transportation cost per ton. The Model takes the following form:

Minimize $Z=\sum_{i=1}^{\mathrm{m}} \sum_{j=1}^{n} D_{i j} X_{i j}$

Subject To $\sum_{j=1}^{n} x_{i j}=\alpha_{i} \quad$ For $\mathrm{i}=1,2 \ldots \ldots \ldots, \mathrm{m}$

$$
\sum_{i=1}^{m} x_{i j}=\beta j \quad \text { For } \mathrm{j}=1,2 \ldots \ldots \ldots, \mathrm{n}
$$

Assuming that

$$
\Sigma \alpha_{i}=\Sigma \beta_{j}
$$

And $\quad \mathbf{X}_{\mathrm{ij}} \geq \mathbf{0} \quad$ for all $(\mathbf{i}, \mathbf{j})$

Where,

$\mathrm{D}_{\mathrm{ij}}=$ Distance between source Governorate (i) and demand Governorate (j) in kilometers under the first scenario,

$X_{\mathrm{ij}}=$ Quantity of fish transported from source Governorate (i) to demand

Governorate (j) in tons,

$\alpha_{\mathrm{i}}=$ Fish quantity available at source $\mathrm{i}$,

$\beta_{\mathrm{j}}=$ Fish quantity demanded at source $\mathrm{j}$,

$\mathrm{m}=$ Number of source (supply surplus) Governorates,

$\mathrm{n}=$ Number of demand Governorates.

The first constraint states that the sum of quantities transported from a supply surplus Governorate (i) to all supply shortage Governorates (j) must equal the surplus of that Governorate $\left(\alpha_{i}\right)$, i.e., total demand must equal total supply. The second constraint states that the sum of quantities transported to a certain supply shortage Governorate (j) from all supply surplus Governorates (i) must equal the shortage in this Governorate $\left(\beta_{\mathrm{j}}\right)$. And the third constraint states that the spatially transported quantity from a supply surplus to a supply shortage Governorate must be greater than or equal to zero. Under the second scenario, the same model has been reapplied using transportation cost instead of distance. To achieve that, $D_{i j}$ has been replaced by $C_{i j}$ in 
the model, which is the transportation cost per ton of fresh fish transported from source Governorate (i) to demand Governorate (j).

As regards the sources of data, the research depended on Fish Statistics Yearbook published by the General Authority For Fish Resources Development (GAFRD); statistical database of The Central Agency For Public Mobilization and Statists (CAPMAS); Google maps for distances between capitals of Egyptian Governorates; and finally staff members of the Central Laboratory for Fish Research in Abbasa who provided estimates of average fish transportation cost.

\section{Relative Importance of Fresh Fish Production by Governorate}

Food availability is one of the main factors affecting food security, but at the same time it is affected by domestic production that plays an important role in food availability. Apart from the prevalent environmental conditions, fish availability for consumers' in Egypt is influenced by the geographic location of different Governorates, and the locations of fish culture activities. Therefore, it is important to study the relative importance of fish produced by different Governorates in Egypt.

Table (1) illustrates the relative importance of average fish production for the period 2011-2013. It is clear that Kafr El-Sheikh ranked first with average production quantity amounting to 607.979 tons, i.e., 44.24\% of Egypt's average fish production, estimated at 1374.394 thousand tons for the same period. Port Said, Behera, Sharkia, and Damietta Governorates followed with production quantities estimated at 175.488, $127.321,112.255$, and 86.341 thousand tons, representing $12.77 \%, 9.26 \%, 8.17 \%$, and $6.28 \%$ of Egypt's average production, respectively. Together, production of the five mentioned Governorates reached some 1109.39 thousand tons representing $80.72 \%$ of the total quantity of fresh fish produced at the country level.

Ranking the remaining Governorates in terms of production volume reveals that Dakahlia, Red Sea, Aswan, Alexandria, Fayoum, Ismailia, and Suez followed the aforementioned top five Governorates, respectively, with production quantities estimated at 66.510, 30.221, 26.361, 24.142, 22.642, 14.743, and 14.327 thousand tons, representing $4.839 \%, 2.199 \%, 1.918 \%, 1.757 \%, 1.647 \%, 1.073 \%$, and $1.042 \%$ of Egypt's average production, respectively. Total production by the seven Governorates reached some 198.946 thousand tons, representing $14.475 \%$ of the total quantity of fresh fish produced at the country level.

Adding up, it is clear that total production obtained from the top twelve Governorates reached about 1308.331 thousand tons, i.e., 95.193\% of Egypt's total fresh fish production, which means that production obtained from the remaining fifteen Governorates represents only $4.807 \%$ of Egypt's domestic production of fresh fish.

\section{Relative Importance of Fresh Fish Consumption Needs by Governorate}

Estimating average consumption needs of fresh fish over the period 2011-2013 revealed that Greater Cairo's (Cairo and Giza) needs approximately 268.898 thousand tons, i.e., 19.3\% of Egypt's total consumption needs of fresh fish, estimated at 1393.235 thousand tons. Sharkia, Dakahlia, and Behera ranked third to fifth with consumption needs estimated at 102.785, 94.882, and 91.417 thousand tons, representing $7.377 \%, 6.810 \%$, and $6.562 \%$ of Egypt's total fish consumption needs, respectively, i.e., 20.749\% in total. Qalyoubia, Menia, Alexandria, Gharbia, and Sohag ranked sixth to tenth with consumption needs estimated at 81.197, 80.197, 76.982, 75.808, and 72.316 thousand tons, representing 5.828\%, 5.806\%, 5.525\%, 


\section{Y 17 Optimum Distribution of Fish Production Between Egyptian Governorates}

$5.441 \%$, and 5.191\% of Egypt's fresh fish consumption needs, respectively, which is $27.791 \%$ in total. Assiut, Menofia, Kafr El-Shaikh, Fayoum, Qena, and Beni Sweif ranked eleventh to sixteenth with consumption needs estimated at $66.723,62.556$, $50.283,49.470,47.945$, and 44.675 thousand tons, representing $4.789 \%, 4.940 \%$, $3.609 \%, 3.551 \%, 3.441 \%$, and $3.207 \%$ of Egypt's fish consumption needs, respectively, i.e., $23.087 \%$ in total. The remaining eleven Governorates followed with total consumption needs estimated at 126.403 thousand tons, representing $9.073 \%$ of Egypt's total consumption needs of fresh fish.

Table (1): Relative Importance of Average Fish Production, Consumption Needs, Surplus, and Shortage for the Period 2011-2013

\begin{tabular}{|c|c|c|c|c|c|c|c|c|}
\hline \multirow[b]{2}{*}{ Governorate } & \multicolumn{2}{|c|}{ Production $^{(1)}$} & \multicolumn{2}{|c|}{ Consumption Needs $^{(2)}$} & \multicolumn{2}{|c|}{ Surplus } & \multicolumn{2}{|c|}{ Shortage } \\
\hline & Tons & $\begin{array}{l}\text { \% of the } \\
\text { Total }\end{array}$ & Tons & $\begin{array}{c}\text { \% of the } \\
\text { Total }\end{array}$ & Tons & $\begin{array}{c}\text { \%o of the } \\
\text { Total }\end{array}$ & Tons & $\begin{array}{c}\text { \% of the } \\
\text { Total }\end{array}$ \\
\hline Cairo & 1.293 & 0.09 & 148.968 & 10.69 & & & 147.674 & 16.69 \\
\hline Alexandria & 24.142 & 1.76 & 76.982 & 5.53 & & & 52.840 & 5.97 \\
\hline Port Said & 175.488 & 12.77 & 10.699 & 0.77 & 164.789 & 19.03 & & \\
\hline Suez & 14.327 & 1.04 & 9.859 & 0.71 & 4.468 & 0.52 & & \\
\hline Damietta & 86.341 & 6.28 & 21.172 & 1.52 & 65.170 & 7.53 & & \\
\hline Dakahlia & 66.510 & 4.84 & 94.882 & 6.81 & & & 28.372 & 3.21 \\
\hline Sharkia & 112.255 & 8.17 & 102.785 & 7.38 & 9.470 & 1.09 & & \\
\hline Qalyoubia & 11.988 & 0.87 & 81.197 & 5.83 & & & 69.209 & 7.82 \\
\hline Kafr Ěl-Sheikh & 607.979 & 44.24 & 50.283 & 3.61 & 557.697 & 64.40 & & \\
\hline Gharbia & 8.361 & 0.61 & 75.808 & 5.44 & & & 67.447 & 7.62 \\
\hline Menofia & 10.946 & 0.80 & 62.556 & 4.49 & & & 51.610 & 5.83 \\
\hline Behera & 127.321 & 9.26 & 91.417 & 6.56 & 35.904 & 4.15 & & \\
\hline Ismailia & 14.743 & 1.07 & 18.516 & 1.33 & & & 3.773 & 0.43 \\
\hline Giza & 2.409 & 0.18 & 119.930 & 8.61 & & & 117.521 & 13.28 \\
\hline Beni Sweif & 3.500 & 0.25 & 44.675 & 3.21 & & & 41.176 & 4.65 \\
\hline Fayoum & 22.642 & 1.65 & 49.470 & 3.55 & & & 26.828 & 3.03 \\
\hline Menia & 6.906 & 0.50 & 80.895 & 5.81 & & & 73.989 & 8.36 \\
\hline Assiut & 5.394 & 0.39 & 66.723 & 4.79 & & & \begin{tabular}{|l|}
61.329 \\
\end{tabular} & 6.93 \\
\hline Sohag & 2.911 & 0.21 & 72.316 & 5.19 & & & 69.405 & 7.84 \\
\hline Qena & 1.779 & 0.13 & 47.945 & 3.44 & & & 46.165 & 5.22 \\
\hline Aswan & 26.361 & 1.92 & 22.632 & 1.62 & 3.729 & 0.43 & & \\
\hline Luxor & 0.546 & 0.04 & 18.222 & 1.31 & & & \begin{tabular}{|l|}
17.676 \\
\end{tabular} & 2.00 \\
\hline Red Sea & 30.221 & 2.20 & 5.479 & 0.39 & 24.742 & 2.86 & & \\
\hline New Valley & 1.770 & 0.13 & 3.573 & 0.26 & & & 1.803 & 0.20 \\
\hline Matruh & 0.270 & 0.02 & 6.742 & 0.48 & & & 6.472 & 0.73 \\
\hline North Sinai & 6.374 & 0.46 & 6.798 & 0.49 & & & 0.424 & 0.05 \\
\hline South Sinai & 1.614 & 0.12 & 2.711 & 0.19 & & & 1.096 & 0.12 \\
\hline Total & $\mathbf{1 3 7 4 . 3 9 4}$ & 100 & 1393.235 & 100 & 865.968 & 00 & \begin{tabular}{|l|}
884.809 \\
\end{tabular} & 100 \\
\hline
\end{tabular}

(1) Calculated using data collected from Fish Statistics Yearbook, The General Authority of Fish Resources Development, Issues 2011-2013.

(2) Based on per capita share of fresh fish and population statistics, the Central Agency for Public Mobilization and Statistics, 2011-2013.

\section{Fresh Fish Surplus and Shortage by Governorate}

Data in Table (1) indicate surplus and shortage Governorates. It is clear that eight of the 27 Governorates have surplus quantities summing up to a total of 865.968 thousand tons. Kafr El-Sheikh ranked first with a surplus quantity of 557.697 thousand tons, representing $64.402 \%$ of the total surplus. Port Said ranked second with a surplus of 164.789 thousand tons, representing $19.03 \%$ of the total surplus. Together, surplus fish production for the two Governorates accounts for $83.431 \%$ of the total surplus. Damietta, Behera, and Red Sea ranked third to fifth with surplus quantities amounting to $65.170,35.904,24.742$ thousand tons, representing $7.526 \%$, $4.146 \%, 2.857 \%$ of the total surplus. Sharkia, Suez, and Aswan ranked last with 
surplus quantities that reached $9.470,4.468$, and 3.729 thousand tons, representing $1.094 \%, 0.516 \%$, and $0.431 \%$ of the total surplus, respectively.

The same table indicates that the remaining 19 Governorates suffer supply shortage summing up to a total of 884.809 thousand tons. Great Cairo (Cairo and Giza), came on top of the shortage supply Governorates, with a shortage quantity amounting to 265.195 thousand tons, representing $29.972 \%$ of the total shortage. Menia, Sohag, Qalyoubia, Gharbia, and Assiut Governorates followed with shortage quantities summing up to 341.379 thousand tons, representing $38.582 \%$ of the total shortage. Alexandria, Menofia, Qena, Beni Sweif, Dakahlia, Fayoum and Luxor followed with shortage quantities summing up to 264.666 thousand tons, representing $29.912 \%$ of the total shortage. Matruh, Ismailia, New Valley, South Sinai, and North Sinai ranked last with shortage quantities summing up to 13.568 thousand tons, representing $1.533 \%$ of the total shortage quantity.

\section{Results and Discussion}

\section{Optimum Allocation of Fresh Fish Surplus based on Minimized Transportation Distances}

Results regarding the optimum allocation of fresh fish surplus between demand Governorates based on minimized transportation distance are illustrated in Table (2). Presented in descending order, the model suggests allocating Port Said's total fish surplus, estimated at 164.789 thousand tons, as follows: 73.989 thousand tons to Menia, (44.9\%); 51.859 thousand tons to Assiut $(31.5 \%) ; 34.744$ thousand tons to Sohag $(21.1 \%) ; 3.773$ thousand tons to Ismailia $(2.3 \%)$; and 0.424 thousand tons to North Sinai, i.e., $0.3 \%$ of Port Said's total fish surplus.

As for Suez Governorate's total fish surplus, estimated at 4.468 thousand tons, the model suggests allocating 3.372 thousand tons to Qena Governorate $(75.5 \%)$, and 1.096 thousand tons to South Sinai Governorate $(24.5 \%)$.

The model also suggests allocating Dameitta Governorate's total fish surplus, estimated at 65.170 thousand tons, as follows: 36.798 thousand tons to Giza (56.5\%); 28.372 thousand tons to Dakahlia (43.5\%). As regards Sharkia Governorate's surplus supply of fish, estimated at 9.47 thousand tons, the model suggests allocating the entire quantity to Assiut Governorate.

Moreover, the model suggests allocating Kafr El-Sheikh Governorate's total surplus, estimated at 557.697 thousand tons, between ten Governorates: 147.674 and 80.723 thousand tons to Cairo and Giza, respectively, i.e., 228.397 thousand tons $(41 \%) ; 69.209$ thousand tons to Qalyoubia $(12.4 \%) ; 67.447$ thousand tons to Gharbia $(12.1 \%) ; 51.61$ thousand tons to Menofia (9.3\%); 41.176 thousand tons to Beni Sweif $(7.4 \%) ; 34.661$ thousand tons to Sohag $(6.2 \%) ; 26.828$ thousand tons to Fayoum $(4.8 \%) ; 23.408$ thousand tons to Alexandria $(4.2 \%)$; and 14.961 thousand tons to Qena $(2.7 \%)$.

In addition, the model suggests allocating Behera's total fish surplus, estimated at 35.904 thousand tons, between two Governorates: 29.432 thousand tons to Alexandria (82\%); and 6.472 thousand tons to Matruh Governorate (18\%). As for Aswan's total fish surplus, estimated at 3.729 thousand tons, the model suggests allocating the whole quantity to Luxor Governorate.

The model also suggests allocating Red Sea Governorate's total fish supply surplus, estimated at 24.742 thousand tons, between two Governorates: Luxor receives 13.947 thousand tons, i.e., $56.4 \%$; whereas 10.795 thousand tons go to Qena, i.e., $43.6 \%$ of the Governorate's total fish supply surplus. 
Table (2): Optimum Distribution of Fresh Fish Supply from Source to Demand Governorates in Egypt Based on Transportation Distance (1000 Tons)

\begin{tabular}{|c|c|c|c|c|c|c|c|c|c|c|c|}
\hline \multirow{22}{*}{ 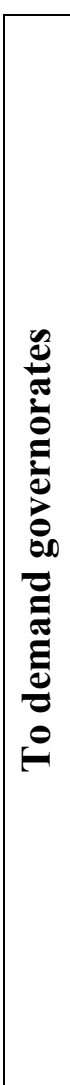 } & \multirow[b]{2}{*}{ Governorate } & \multicolumn{9}{|c|}{ From Source Governorates } & \multirow{2}{*}{$\begin{array}{c}\text { Total Quantity } \\
\text { Transported To } \\
\text { Demand } \\
\text { Governorates }\end{array}$} \\
\hline & & $\begin{array}{l}\text { Port } \\
\text { Said }\end{array}$ & Suez & $\underset{\mathbf{a}}{\text { Damiett }}$ & Sharkia & $\begin{array}{l}\text { Kafr EI- } \\
\text { Sheikh }\end{array}$ & Behera & Aswan & Red Sea & $\begin{array}{l}\text { Unfilled } \\
\text { Demand }\end{array}$ & \\
\hline & Cairo & & & & & 147.674 & & & & & 147.674 \\
\hline & Alexandria & & & & & 23.408 & 29.432 & & & & 52.840 \\
\hline & Dakahlia & & & 28.372 & & & & & & & 28.372 \\
\hline & Qalyoubia & & & & & 69.209 & & & & & 69.209 \\
\hline & Gharbia & & & & & 67.447 & & & & & 67.447 \\
\hline & Menofia & & & & & 51.61 & & & & & 51.610 \\
\hline & Ismailia & 3.773 & & & & & & & & & 3.773 \\
\hline & Giza & & & 36.798 & & 80.723 & & & & & 117.521 \\
\hline & Beni Sweif & & & & & 41.176 & & & & & 41.176 \\
\hline & Fayoum & & & & & 26.828 & & & & & 26.828 \\
\hline & Menia & 73.989 & & & & & & & & & 73.989 \\
\hline & Assiut & 51.859 & & & 9.47 & & & & & & 61.329 \\
\hline & Sohag & 34.744 & & & & 34.661 & & & & & 69.405 \\
\hline & Qena & & 3.372 & & & 14.961 & & & 10.795 & 17.037 & 46.165 \\
\hline & Luxor & & & & & & & 3.729 & 13.947 & & 17.676 \\
\hline & New Valley & & & & & & & & & 1.803 & 1.803 \\
\hline & Matruh & & & & & & 6.472 & & & & 6.472 \\
\hline & North Sinai & 0.424 & & & & & & & & & 0.424 \\
\hline & South Sinai & & 1.096 & & & & & & & & 1.096 \\
\hline & $\begin{array}{c}\text { Total Quantity } \\
\text { Transported From } \\
\text { Source } \\
\text { Governorates }\end{array}$ & 164.789 & 4.468 & 65.17 & 9.470 & 557.697 & 35.904 & 3.729 & 24.742 & 18.840 & 884.809 \\
\hline
\end{tabular}

Source: Analysis results based on data in Table (1). 
Finally, the analysis revealed that there is still unfilled demand estimated at 18.84 thousand tons. Of this total, about 17.037 thousand tons representing $90.4 \%$ need to be fulfilled in Qena; whereas 1.803 thousand tons representing 9.6\% need to be fulfilled in the New Valley.

It is also clear from the table that fish supply shortage in some Governorates can be covered from more than one source Governorate; while in some other demand Governorates can be covered from one source Governorate. However, two of the twenty seven Governorates still suffer either partial or complete unfilled demand.

Starting with the first group, the model suggests that Great Cairo's fish supply shortage can be fully covered from Kafr El-Sheik (86\%), and Dameitta (14\%); Alexandria's shortage can be fully covered from Kafr El-Sheik (44.3\%), and Behera (55.7\%); Assiut's shortage can be fully covered from Port Said (84.6\%), and Sharkia (15.4\%); Sohag's shortage can also be fully covered from Port Said (50.1\%), and Kafr El-Sheik (49.9\%); Qena's shortage can be partially covered from Suez (7.3\%), Kafr El-Sheik (32.4\%), and the Red Sea (23.4\%), whilst the 36.9\% has been recorded as unfilled demand; and finally, Luxor's shortage can be fully covered from Aswan (21.1\%), and the Red Sea (78.9\%).

Turning to the second group, for which fish supply shortage can be fully covered from one source Governorate, the solved model revealed the following: Dakahlia's shortage can be fully covered from Dameitta; whereas Qalyoubia, Gharbia, Menofia, Beni Sweif, and Fayoum Governorate's fish supply shortages can be fully covered from Kafr El-Sheik; Ismailia, Menia, and North Sinai's shortages can be fully covered from Port Said; Matruh's shortage can be fully covered from Behera; and finally, South Sinai's shortage can be fully covered from Suez Governorate. New Valley is the only Governorate which fish supply shortage, estimated at 1.803 thousand tons, has not been covered.

\section{Optimum Allocation of Fresh Fish Surplus based on Minimized Transportation Cost per Ton}

Results regarding the allocation of surplus fish supply between demand Governorates based on transportation cost per ton are illustrated in Table (3). Presented in descending order, the model suggests allocating Port Said's total fish surplus, estimated at 164.789 thousand tons, as follows: 138.204thousand tons to Cairo (83.9\%), 22.388 thousand tons to Giza (13.6\%), which means that Great Cairo receives 160.592 thousand tons representing $97.5 \%$ of Port Said's total fish surplus. The remaining quantity is suggested to be allocated between Ismailia (3.773 thousand tons representing $2.3 \%$ ), and North Sinai (0.424 thousand tons representing $0.3 \%$ ).

As for Suez Govern rate's total fish surplus, estimated at 4.468 thousand tons, the model suggests allocating 3.372 thousand tons to Assiut (75.5\%), and 1.096 thousand tons to South Sinai $(24.5 \%)$.

Dameitta's entire surplus, estimated at 65.170 thousand tons, is suggested to go to Giza; and Sharkia's entire surplus, estimated at 9.47 thousand tons, to Cairo.

As for Kafr El-Sheikh, the model suggests allocating the Governorate's total surplus, estimated at 557.697 thousand tons, between eleven Governorates as follows: 52.840 thousand tons to Alexandria $(9.5 \%), 28.372$ thousand tons to Dakahlia (5.1\%), 69.209 thousand tons to Qalyoubia (12.4\%), 67.447 thousand tons to Gharbia (12.1\%), 51.610 thousand tons to Menofia (9.3\%), 29.963 thousand tons to Giza (5.4\%), 41.176 thousand tons to Beni Sweif (7.4 \%), 26.828 thousand tons to Fayoum 
Table (3): Optimum Distribution of Fresh Fish Supply from Source to Demand Governorates Based on Transportation

Cost per Ton (1000 Tons)

\begin{tabular}{|c|c|c|c|c|c|c|c|c|c|c|c|}
\hline & & & & & From & Source G & ernorate & & & & Total Quantity \\
\hline & Governorate & Port Said & Suez & Damietta & Sharkia & $\begin{array}{c}\text { Kafr El- } \\
\text { Sheikh }\end{array}$ & Behera & Aswan & Red Sea & $\begin{array}{l}\text { Unfilled } \\
\text { Demand }\end{array}$ & $\begin{array}{c}\text { Transported To } \\
\text { Demand } \\
\text { Governorates }\end{array}$ \\
\hline & Cairo & 138.204 & & & 9.470 & & & & & & 147.674 \\
\hline & Alexandria & & & & & 52.840 & & & & & 52.840 \\
\hline & Dakahlia & & & & & 28.372 & & & & & 28.372 \\
\hline & Qalyoubia & & & & & 69.209 & & & & & 69.209 \\
\hline$\stackrel{ِ ّ}{=}$ & Gharbia & & & & & 67.447 & & & & & 67.447 \\
\hline 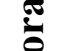 & Menofia & & & & & 51.610 & & & & & 51.610 \\
\hline  & Ismailia & 3.773 & & & & & & & & & 3.773 \\
\hline$\overline{0}$ & Giza & 22.388 & & 65.170 & & 29.963 & & & & & 117.521 \\
\hline e & Beni Sweif & & & & & 41.176 & & & & & 41.176 \\
\hline 0 & Fayoum & & & & & 26.828 & & & & & 26.828 \\
\hline 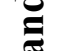 & Menia & & & & & 73.989 & & & & & 73.989 \\
\hline$\stackrel{\coprod}{\Xi}$ & Assiut & & 3.372 & & & 57.957 & & & & & 61.329 \\
\hline$\frac{\pi}{2}$ & Sohag & & & & & 58.306 & 11.099 & & & & 69.405 \\
\hline 0 & Qena & & & & & & 24.805 & & 10.795 & 10.565 & 46.165 \\
\hline$F$ & Luxor & & & & & & & 3.729 & 13.947 & & 17.676 \\
\hline & New Valley & & & & & & & & & 1.803 & 1.803 \\
\hline & Matruh & & & & & & & & & 6.472 & 6.472 \\
\hline & North Sinai & 0.424 & & & & & & & & & 0.424 \\
\hline & South Sinai & & 1.096 & & & & & & & & 1.096 \\
\hline & $\begin{array}{c}\text { Total Quantity } \\
\text { Transported From } \\
\text { Source Governorates }\end{array}$ & 164.789 & 4.468 & 65.170 & 9.470 & 557.697 & 35.904 & 3.729 & 24.742 & 18.840 & 884.809 \\
\hline
\end{tabular}

Source: Analysis Results based on data in Table (1). 
(4.8\%), 73.989 thousand tons to Menia (13.3\%), 57.957 thousand tons to Assiut (10.4\%), and finally, 58.306 thousand tons to Sohag (10.5\%).

In addition, the model suggests allocating Behera's total fish surplus, estimated at 35.904 thousand tons, between two Governorates: 11.099 thousand tons to Sohag (31\%), and 24.805 thousand tons to Qena (69\%).

As for Aswan's total surplus, estimated at 3.729 thousand tons, the model suggests allocating the entire quantity to Luxor Governorate.

Finally, the model suggests allocating the Red Sea's total surplus, estimated at 24.742 thousand tons, as follows: 10.795 thousand tons to Qena (43.6\%); and 13.947 thousand tons to Luxor (56.4\%).

Analysis results also revealed that three Governorates still suffer unfilled demand amounting to 18.84 thousand tons. Of this total, about 10.565 thousand tons need to be fulfilled in Qena $(56.1 \%) ; 1.803$ thousand tons need to be fulfilled in the New Valley (9.6\%); and 6.472 thousand tons need to be fulfilled in Matruh $(34.4 \%)$.

It is also clear that fish supply shortage in some Governorates can be fully covered from several source Governorates; while in some others can be fully covered from one source Governorate. However, three of the twenty seven Governorates still suffer either partial, or complete unfilled demand.

Starting with the first group, the model suggests that Cairo's fish supply shortage can be fully covered from Port Said (93.6\%), and Sharkia (6.4\%); Giza's shortage can be fully covered from Port Said (19.1\%), Dameitta (55.5\%), and Kafr El-Sheik (25.5\%); Assiut's shortage can be fully covered from Suez (5.5\%), and Kafr El-Sheik (94.5\%); Sohag's shortage can be fully covered from Kafr El-Sheik (84\%), and Behera (16\%); Qena's shortage can be partially covered from Behera (53.7\%), and the Red Sea (23.4\%), whereas the remaining $22.9 \%$ has been recorded as unfilled demand, meaning that Qena's demand has not been fully covered. As for Luxor's fish supply shortage, the model suggests that it can be fully covered from Aswan (21.1\%), and the Red Sea (79\%).

Turning to the second group, for which fish supply shortage can be fully covered from one source Governorate, the solved model revealed that shortage in Alexandria, Dakahlia, Qalyoubia, Gharbia, Menofia, Beni Sweif, Fayoum, and Menia can be fully covered from Kafr El-Sheikh; whereas North Sinai's shortage can be fully covered from Port Said. New Valley and Matruh are the only Governorates which fish shortages have not been covered at all.

\section{Total Reduced Cost}

Another interesting result that was obtained from the two minimization scenarios is the total reduced cost of transporting fresh fish from each of the eight source Governorates, to all of nineteen destination Governorates. As illustrated in Table (4), the total reduced cost of transporting fresh fish amounted to LE 54906 under the first scenario; whilst amounted to LE 63750 under the second scenario, indicating that optimum distribution of fresh fish based on minimized transportation cost saves more money.

Knowing that Egyptian consumers prefer to eat fresh fish, which is a fast perishable food commodity, such reductions are expected to have two main positive impacts. The first is the reduced market prices thus improved consumers' access to fresh fish as a cheaper source of animal protein; whereas the second is the better quality thus health benefits of the transported fish based on the way fresh fish is 


\section{Y I T Optimum Distribution of Fish Production Between Egyptian Governorates}

handled and transported in Egypt, where the product is usually packed into plastic boxes with crushed or salt ice between layers, then transported in semi-trucks to different destinations across the country. No doubt, minimizing the transportation distances is expected to maintain a better nutritional value of fresh fish.

Table (4): Total Reduced Transportation Distance and Corresponding Cost

\begin{tabular}{|l|c|c|c|}
\hline \multirow{2}{*}{ From Source Governorates } & \multirow{2}{*}{ To Destination Governorates } & \multicolumn{2}{|c|}{$\begin{array}{c}\text { Total } \\
\text { (LE) }\end{array}$} \\
\cline { 3 - 4 } & & 3223 & Second Scenario \\
\hline Port Said & All Demand Governorates & 7803 & 6800 \\
\hline Suez & All Demand Governorates & 1907 & 2800 \\
\hline Dameitta & All Demand Governorates & 3083 & 4500 \\
\hline Sharkia & All Demand Governorates & 1834 & 1650 \\
\hline Kafr El-Sheikh & All Demand Governorates & 4102 & 2300 \\
\hline Behera & All Demand Governorates & 21285 & 23750 \\
\hline Aswan & All Demand Governorates & 11669 & 14750 \\
\hline Red Sea & All Demand Governorates & 54906 & 63750 \\
\hline Gross Total & & \multicolumn{2}{|}{} \\
\hline
\end{tabular}

Source: Calculated based on analysis results

\section{Recommendations}

Although findings revealed that optimum distribution of fresh fish based on minimized transportation cost saves more money, the research does not intend to recommend choosing this scenario over the other. Rather, it aims to provide policy makers with two possible scenarios for optimizing the distribution of fresh fish to help them formulate appropriate polices regarding the infrastructure and logistics required for improving consumers' access to and affordability of obtaining adequate amounts of animal protein. The difficulty of choosing between the two scenarios comes from the fact that fish transportation is mostly performed by private trucks, the owners of which decide which road to use based on security conditions. Therefore, the research suggests the following two sets of recommendations:

a. Based on findings obtained from the two minimization scenarios, it is recommended to:

1. Promote the coordination between responsible authorities to establish an adequate fish transportation fleet and specify the appropriate health and technical standards, in addition to performing periodic inspection of the trucks.

2. Apply the international standards to the network of roads connecting Egyptian Governorates, in addition to performing periodic maintenance in order to accelerate the arrival of a fast perishable commodity like fish to destination Governorates thus maintain its nutrition value.

3. Establish a complete database that monitors the fish transportation operations, including transportation routes, quantities transported from source to destination Governorates, and transportation costs.

4. Exploring the possibility of establishing a properly equipped marine and river transportation fleet as a shorter and faster mean of fish transportation between Governorates wherever applicable.

\section{b. Based on the calculated shortage figures, it is recommended to:}

1. Encourage the activation of Egyptian laws and legislations governing the fishing practices, as well as the laws and legislations governing the disposal of agricultural drainage, industrial waste, and sewage in the Nile River, Seas, and Inland lakes, which shall eventually lead to rebuilding the fish stock in natural fisheries

2. Conduct research studies that aim to identify the reasons behind fish supply shortage in coastal Governorates endowed with natural fisheries, especially 
Alexandria and Ismailia, in order to find proper solutions for addressing this serious problem.

3. Arrange coordination protocols between relevant authorities for renovating and developing the fishing fleet and establishing maintenance workshops.

4. Establish fishermen cooperative societies and fishermen Fund to provide members with services and finance.

\section{Summary}

Fishes, either from natural resources or cultured, are considered the safe haven for providing consumers with a cheaper source of healthy animal protein that can help them cover their body requirements. The research investigates the problem of unplanned transportation of fresh fish across Egypt, which causes inequality in consumers' access to, and affordability of obtaining fresh fish as a cheaper source of animal protein, the deficiency of which risks human health thus economic performance of the population.

Therefore, the research aimed to provide decision makers with two possible options regarding the optimum pattern of transporting domestic production of fresh fish from supply to demand Governorates. The research depended on applying the Transportation Model to fresh fish transported from source to demand Governorates under two scenarios, the first of which is the minimization of transportation distances, and the second is the minimization of transportation cost per ton.

Findings based on the first scenario indicate the following optimum distribution of fresh fish surplus between demand Governorates: - Port Said's total fish surplus, estimated at 164.789 thousand tons, is better allocated between Menia (44.9\%), Assiut (31.5\%), Sohag (21.1\%), Ismailia (2.3\%), and North Sinai (0.3\%). - Suez Governorate's total fish surplus, estimated at 4.468 thousand tons, is better allocated between Qena (75.5\%), and South Sinai (24.5\%). - Dameitta's total fish surplus, estimated at 65.170 thousand tons, is better allocated between Giza $(56.5 \%)$, and Dakahlia (43.5\%). - Sharkia's entire surplus fish supply, estimated at 9.47 thousand tons, goes to Assiut Governorate. - Kafr El-Sheikh's total fish surplus, estimated at 557.697 thousand tons, is better allocated between ten Governorates: Cairo and Giza (41\%), Qalyoubia (12.4\%), Gharbia (12.1\%), Menofia (9.3\%), Beni Sweif (7.4 \%), Sohag (6.2 \%), Fayoum (4.8\%), Alexandria (4.2\%), and Qena (2.7\%). - Behera's total fish surplus, estimated at 35.904 thousand tons, is better allocated between Alexandria (82\%); and Matruh (18\%). - As for Aswan's total fish surplus, estimated at 3.729 thousand tons, the model suggests allocating the entire quantity to Luxor Governorate. - Red Sea Governorate's total fish surplus, estimated at 24.742 thousand tons, is better allocated between Luxor (56.4\%), and Qena (43.6\%). - There still exists unfilled demand estimated at 18.84 thousand tons, $90.4 \%$ of this total needs to be fulfilled in Qena; whereas 9.6\% needs to be fulfilled in the New Valley.

Findings based on the second scenario indicate the following optimum distribution of fresh fish surplus between demand Governorates: - Port Said's fish surplus, estimated at 164.789 thousand tons, is better allocated between Great Cairo (97.5\%), Ismailia (2.3\%), and North Sinai (0.3\%). - Suez Governorate's fish surplus, estimated at 4.468 thousand tons, is better allocated between Assiut $(75.5 \%)$, and South Sinai (24.5\%). - Dameitta's entire fish surplus, estimated at 65.170 thousand tons, is better allocated to Giza. - Sharkia's entire fish surplus, estimated at 9.47 thousand tons, is better allocated to Cairo. - Kafr El-Sheikh's fish surplus, estimated at 557.697 thousand tons, is better allocated between eleven Governorates, these are Alexandria (9.5\%), Dakahlia (5.1\%), Qalyoubia (12.4\%), Gharbia (12.1\%), Menofia (9.3\%), Giza (5.4\%), Beni Sweif (7.4\%), Fayoum (4.8\%), Menia (13.3\%), Assiut 
(10.4\%), and Sohag (10.5\%). - Behera's fish surplus, estimated at 35.904 thousand tons, is better allocated between Sohag (31\%); and Qena (69\%). - Aswan's entire fish surplus, estimated at 3.729 thousand tons, is better allocated to Luxor. - Red Sea Governorate's fish surplus, estimated at 24.742 thousand tons, is better allocated between Qena (43.6\%); and Luxor (56.4\%).

Three Governorates still suffer unfilled demand amounting to 18.84 thousand tons. Of this total, $56.1 \%$ needs to be fulfilled in Qena, 9.6\% needs to be fulfilled in the New Valley, and $34.4 \%$ needs to be fulfilled in Matruh. The calculated total reduced cost of transporting fresh fish from surplus to demand Governorates amounted to LE 54906 under the first scenario; whilst amounted to LE 63750 under the second scenario, which is expected to have two main positive impacts. The first is the reduced market prices thus improved consumers' access to fresh fish as a cheaper source of animal protein; whereas the second is the better quality thus health benefits of the transported fish.

Despite finding that optimum distribution of fresh fish based on minimized transportation cost saves more money, the research did not intend to recommend choosing this scenario over the other. Rather, it provides policy makers with two possible scenarios for optimizing the distribution of fresh fish to help them formulate appropriate polices regarding the infrastructure and logistics required for improving consumers' access to and affordability of obtaining adequate amounts of animal protein. The difficulty of choosing between the two comes from the fact that fish transportation is mostly performed by private trucks, the owners of which decide which road to use based on security conditions.

Finally, the research recommended promoting the coordination between responsible authorities to establish an adequate fish transportation fleet and encourage the activation of Egyptian laws and legislations governing the fishing practices, as well as banning the disposal of different wastewater types in natural fisheries, and exploring the possibility of establishing a properly equipped marine and river transportation fleet as a shorter and faster mean of fish transportation between Governorates wherever applicable.

\section{References}

1. Environmental Defense Fund Site, http://seafood.edf.org/benefits-eating-fish, the internet.

2. Live Strong Site, http://www.livestrong.com/article/109157-animal-sourcesprotein-advantages, the internet.

3. The General Authority for Fish Resources Development (GAFRD), Fish Statistics Yearbook, 2011-2013.

4. The Central Agency for Public Mobilization and Statistics (CAPMAS), Statistical Database, 2011-2013.

5. The Central Laboratory for Fish Research in Abbasa, Agricultural Research Centre, 2014.

6. Google maps Site, https://www.google.com/maps, the internet.

7. Adel Ghanim (Dr.); "Economic Planning for the Distribution of Fish fry Among Different Fish-Farms in Egyptian Governorates", Bulletin of Science and Development Research, Faculty of Agriculture, Vol.46, Alexandria University, 1994.

8. Jin Y. Wang; "Operation Research I", College of Management, National Chiao Tung University, Chap8, pp.1:20, 2008. 
rIV. المحلة المصرية للاقتصاد الزراعي - الخامس و العشرون - العدد الرابع - ديسمبر (ب) ه 10

\section{التوزيع الأمثل للإنتاج السمكي بين محافظات مصر

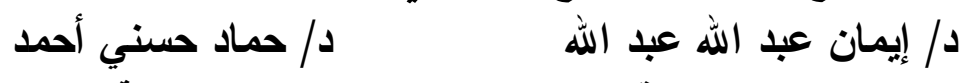 \\ معهز بحوث الاقتصاد الزراعي -مركز البحوث الزراعية}

الملخص

يُعد البروتين الحيواني من أهم المجموعات الغذائية الضرورية لبناء جسم الإنسان. لذا فان توفير احتياجات المستهلك من البرونين الحيو اني يأتي على رأس أولويات صانعي السياسة الغذائية في مصر • ولكن

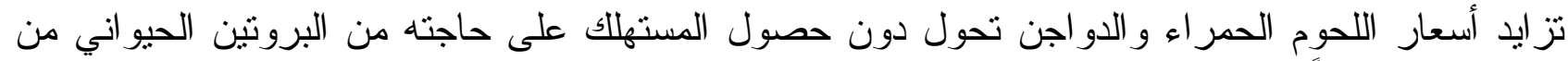

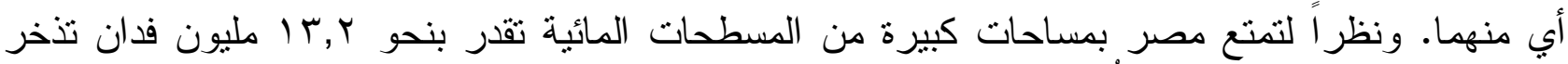

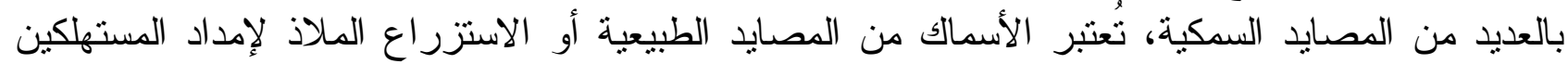

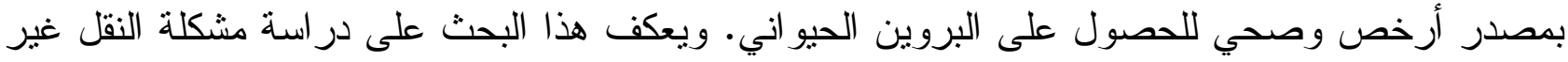
المخطط للأسماك الطازجة عبر المحافظات، و الذي يؤدي إلى عدم المساو اة بين المستهلكين من حيث مدى ولى

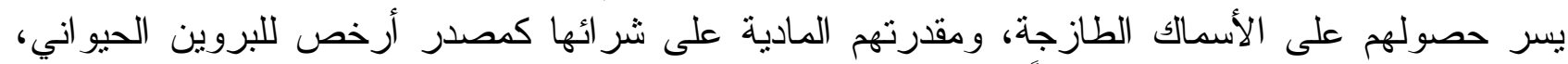

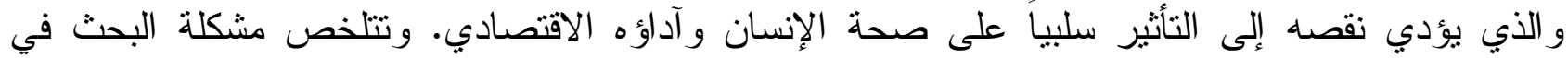
الإجابة على السؤال التالي: هل يمكن إمداد صانعي السياسة بخيار ات مدروسة لتحقيق التوزيع الأمنل لإنتاج

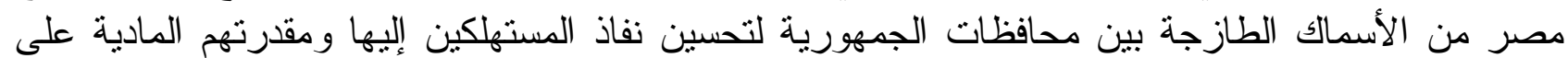
شر ائها كبديل أرخص للبروين الحيو اني؟. وبالتالي فقد انصب الهدف الأساسي لهذا البحث على إمداد صانعي السياسة بخيارين لنقل الأسماك الطازجة من محافظات الفائض إلى محافظات العجز ، و الذان يحققان التوزيع الأمثل لإنتاج مصر من الأسماك الطازجة بين محافظات الجمهورية. وللوصول إلى هدف البحث البـ اعتمد البحث على تطبيق نموذج النقل السمكي على الأسماك الطازجة التي يجب نقلها من محافظات الفائض إلى دلى الألى

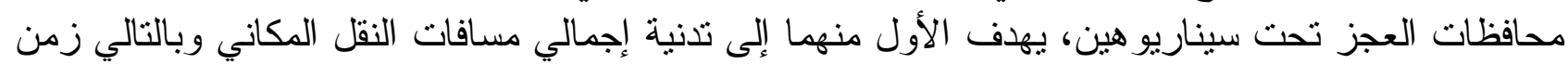
النقل، بينما بهدف الثاني إلى تدنية إجمالي تكلفة النقل وبالتالي خفض أستان أسعار المستهلك. وقد أوضحت نتائج در اسة منوسط إنتاج محافظات مصر من الأسماك الطازجة ومتوسط الإنة الاحتياجات

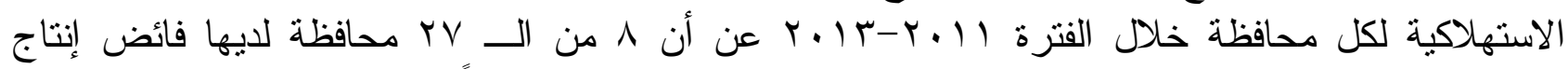

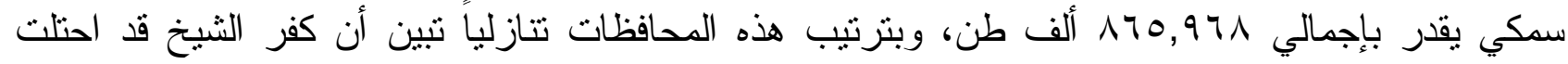

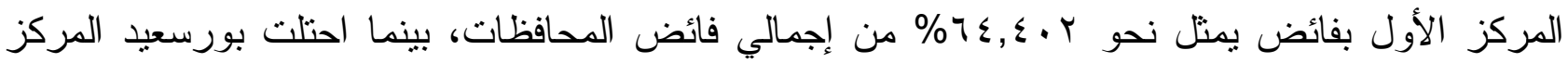

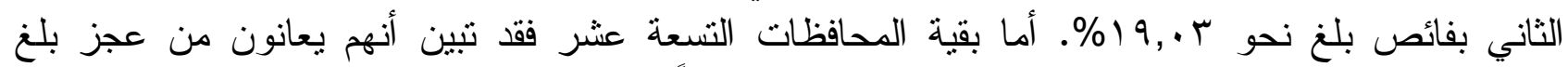

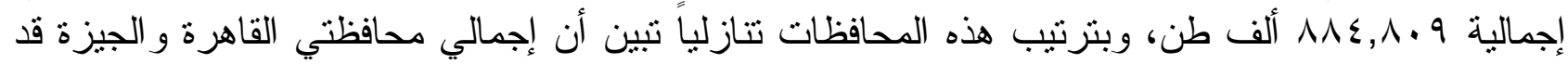
شغلت المركز الأول بكمية عجز سمكي تمثل . ب\% من إجمالي العجز السمكي؛ و جاءت في الترتيب النهائي محافظات مطروح، الاسماعيلية، الو ادي الجديد، جنوب سيناء، شمال سيناء بكميات عجز سمكي تمثل ولث مجتمعة نحو 0, 1, من من إجمالي العجز السمكي.

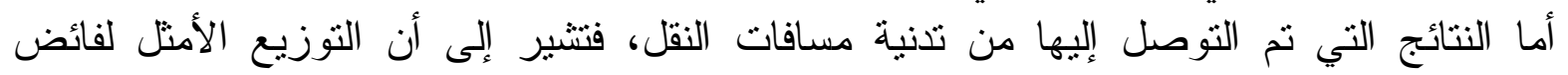

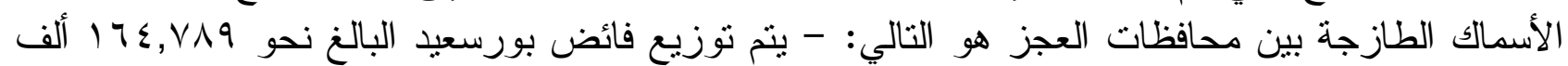

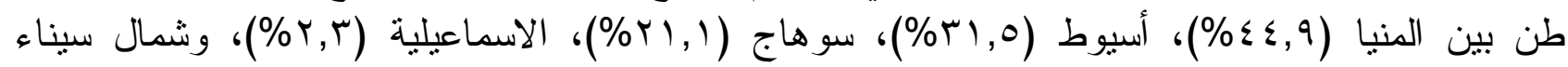

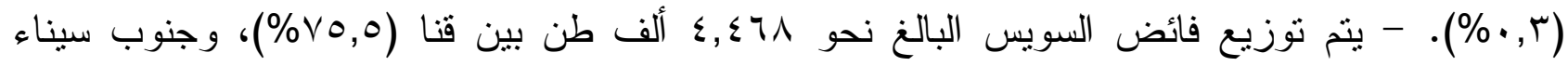



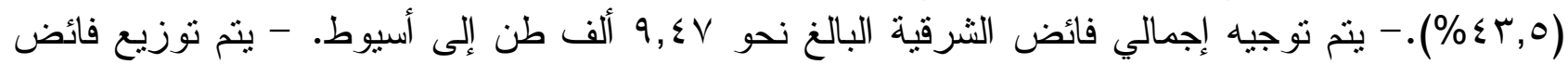



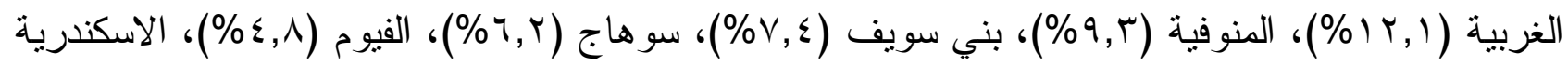

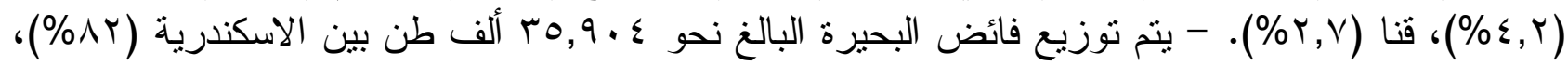




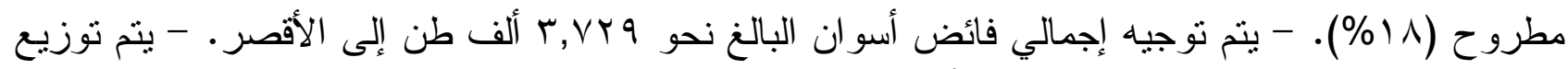

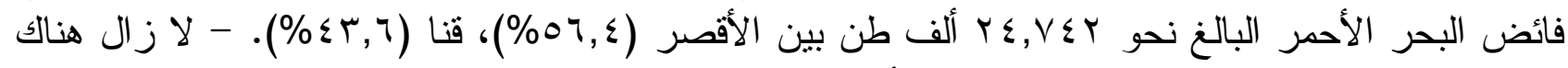

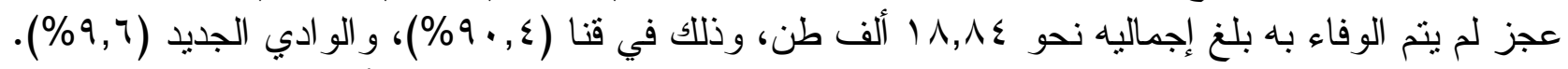



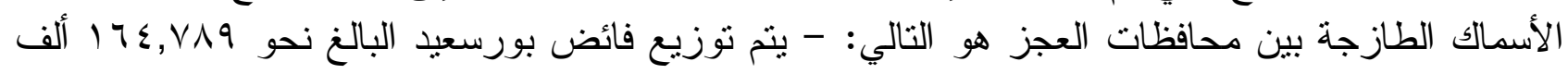

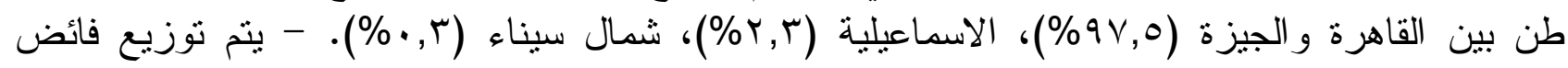

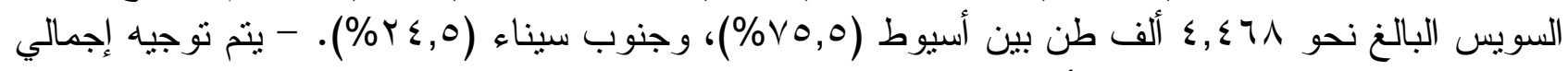

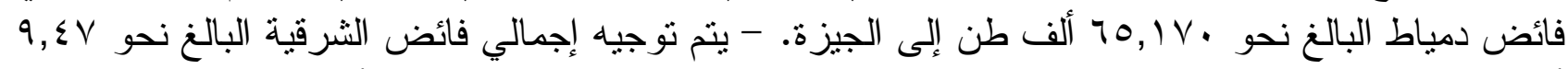

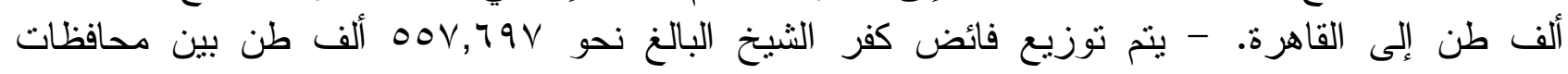

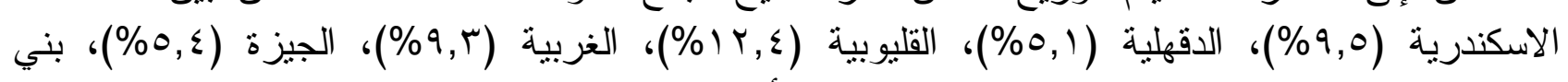

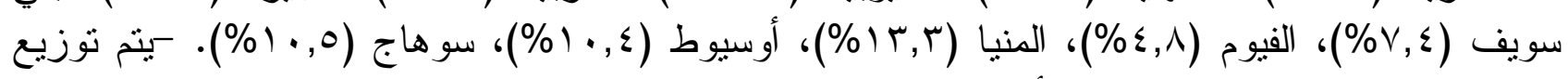

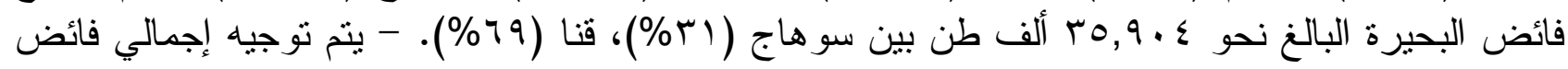

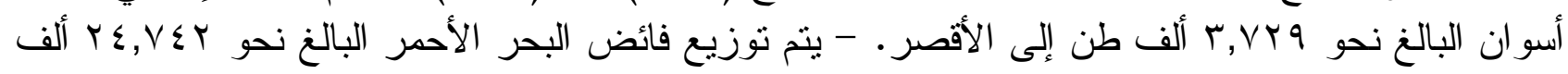

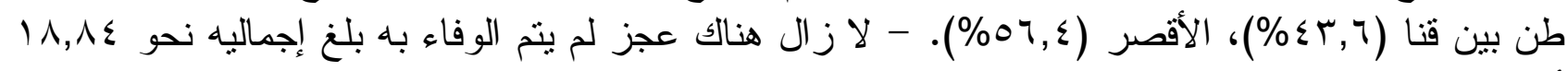

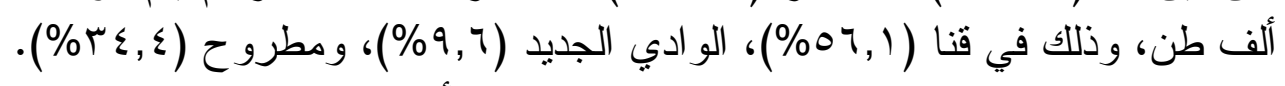

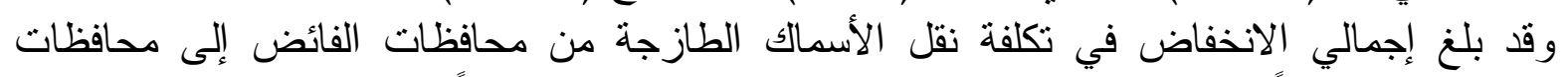

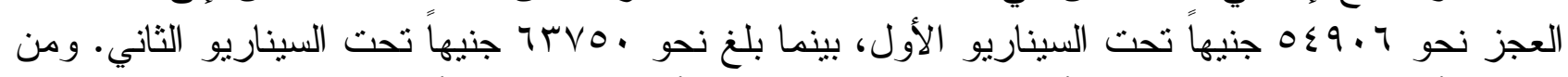

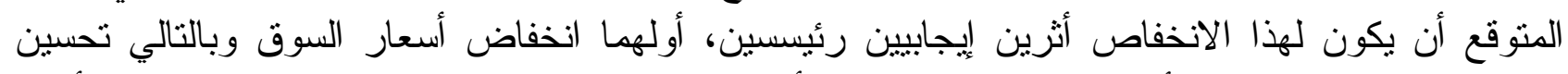

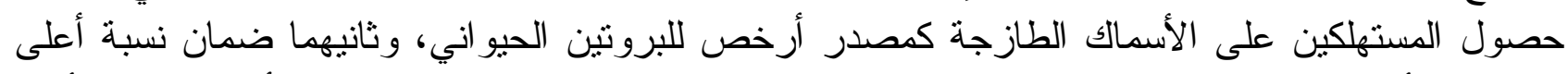

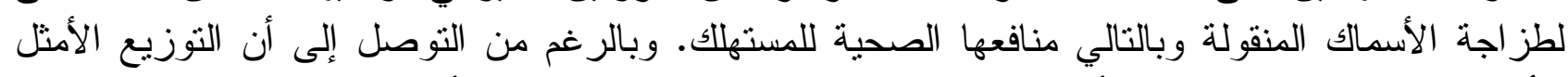

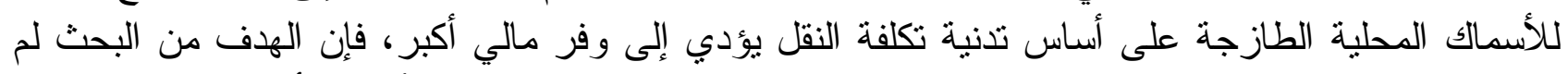

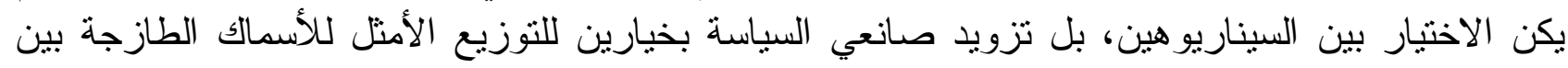

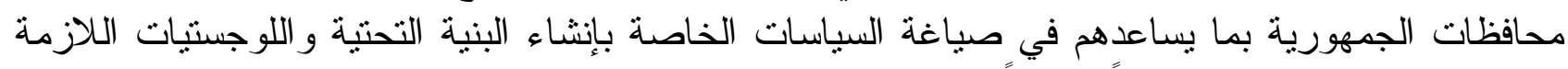

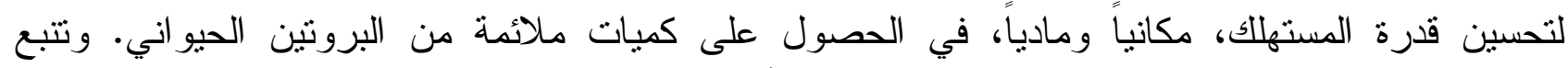



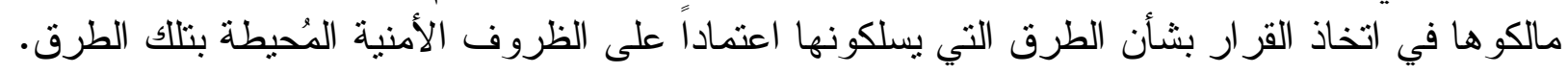

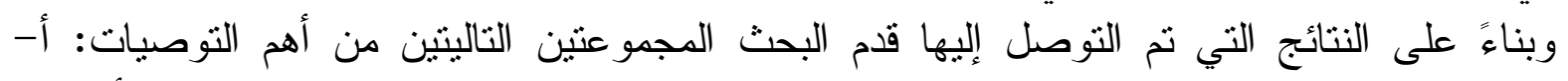

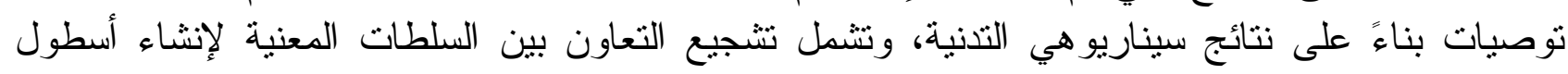

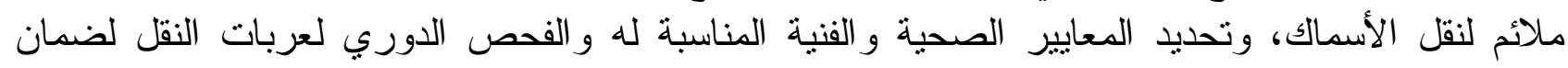

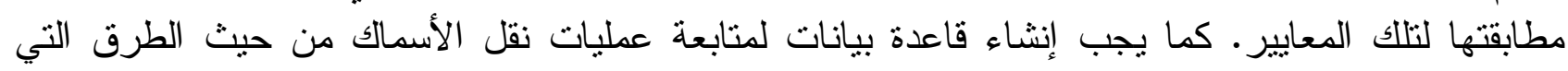

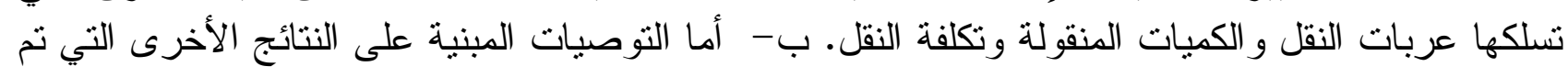

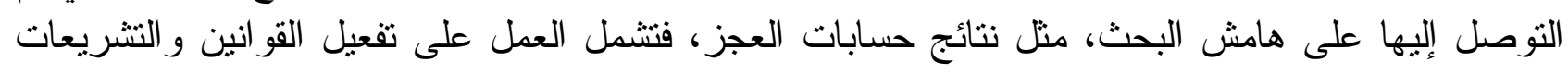

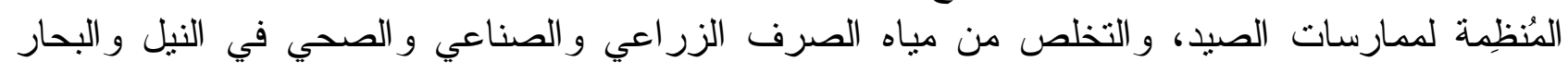

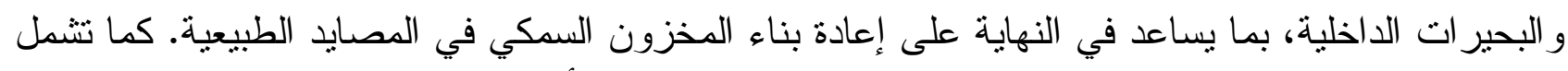

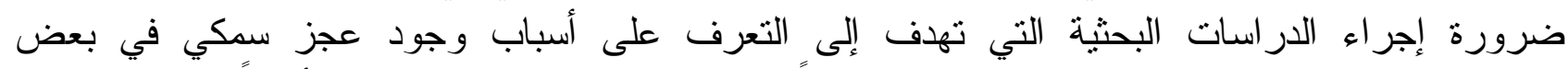

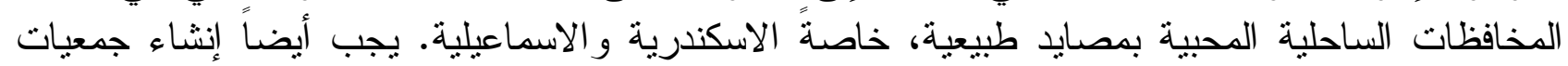
تعاونية وصندوق للعاملين بحرفة الصيد. 